Kevin, Widayatmoko, Muhammad Adi Pribadi : Pengaruh Fungsi Iklan Dan Citra Merek Terhadap Loyalitas Pelanggan Gojek

\title{
Pengaruh Fungsi Iklan Dan Citra Merek Terhadap Loyalitas Pelanggan Gojek
}

\author{
Kevin, Widayatmoko, Muhammad Adi Pribadi \\ vinkevinnnn@yahoo.com,widayatmoko@fikom.untar.ac.id,adip@fikom.untar.ac.id
}

Fakultas Ilmu Komunikasi Universitas Tarumanagara

\begin{abstract}
Online transportation is a business that sells services that require loyal customers and ultimately create customer loyalty. Customer loyalty to a brand is an absolute thing that is needed by a brand to remain in their business. Likewise with Go-jek, to get appreciation from consumers, innovation is needed in promoting transportation services, one of which is by placing online advertisements. Gojek offers a variety of services that can be used by its customers, namely: Go-Box, Go-Ride, Go-Shop and Go-Food (Food / Beverage Courier Services) which emphasize excellence in Speed, Innovation and Social Interaction. This study aims to determine the effect of Gojek advertising and brand image on the loyalty of Gojek customers. The theory used in this research is advertising theory, namely precipitation function, persuation function, reinforcement function, reminder function. Brand image theory, namely strength, uniqueness and popularity, and customer loyalty theory, namely order of purchase, proportion of purchases, preferences and commitments. The research method used is a quantitative research method with a survey method. The population in this study was 8 million Gojek users in Jakarta with a 100 respondents sampel. The sampling technique of this study was purposive sampling. The validity technique of the data used is the classic assumption test. The data analysis technique is done by testing the multiple relation coefficient, multiple linear regression analysis, coefficient of determination and hypothesis testing which consists of $T$ test and $F$ test. In addition, Gojek advertisements and brand image have a significant influence on the loyalty of Gojek customers.
\end{abstract}

Keywords: Ad Function, Brand Image, Customer Loyalty

\begin{abstract}
Abstrak
Transportasi online merupakan suatu bisnis yang menjual jasa sehingga membutuhkan pelanggan yang loyal. Loyalitas pelanggan terhadap suatu brand adalah hal mutlak yang diperlukan sebuah brand untuk tetap exist dalam bisnis mereka. Begitu juga dengan Gojek, mendapatkan pelanggan yang loyal maka gojek melakukan inovasi dalam hal periklanan online. Gojek juga memperhatikan citra positif di benak konsumen agar membentuk konsumen yang loyal. Penelitian ini bertujuan Untuk mengetahui pengaruh fungsi iklan dan citra merek terhadap loyalitas pelanggan Gojek. Teori yang digunakan dalam penelitian ini adalah teori fungsi iklan yang terdiri dari fungsi precipitation, fungsi persuation, fungsi reinforcement, fungsi reminder. Disamping itu, juga dibahas tentang teori citra merek yang menyangkut tentang kekuatan, keunikan dan favourable. Selain itu, turut dibahas teori loyalitas pelanggan yang terdiri dari urutan pembelian, proporsi pembelian, preferensi dan komitmen. Metodologi dari penelitian ini adalah kuantitatif. Populasi dalam penelitian ini adalah 8 juta pengguna Gojek di Jakarta
\end{abstract}


dengan sampel sebanyak 100 responden. Teknik pengambilan sampel dari penelitian ini adalah purposive sampling. Teknik keabsahan data yang digunakan adalah uji asumsi klasik. Teknik analisis data dilakukan dengan uji koefisien relasi berganda, analisis regresi linear berganda, koefisien determinasi serta uji hipotesis yang terdiri dari uji T dan uji F. Hasil penelitian ini menunjukan bahwa fungsi iklan dan citra merek bernilai positif sehingga jika ada kenaikan fungsi iklan dan citra merek maka akan meningkatkan loyalitas pelanggan. Sehingga kesimpulannya adalah fungsi iklan berpengaruh terhadap loyalitas pelanggan Gojek dan juga citra merek berpengaruh terhadap loyalitas pelanggan Gojek. Selain itu, fungsi iklan dan citra merek Gojek memberikan pengaruh signifikan terhadap loyalitas pelanggan Gojek.

Kata Kunci : Fungsi Iklan, Citra Merek, Loyalitas Pelanggan

\section{Pendahuluan}

Transportasi online merupakan transportasi yang dapat diakses melalui aplikasi pada smartphone. Transportasi online sangat memudahkan pelanggan karena dapat diakses melalui internet. Salah satu perusahaan transportasi online adalah PT. Gojek Indonesia. PT. Gojek Indonesia adalah perusahaan transportasi online dengan merek Gojek. Gojek merupakan suatu bisnis yang menjual jasa sehingga membutuhkan pelanggan yang loyal. Loyalitas pelanggan sangat penting bagi perusahaan karena pelanggan yang loyal adalah modal bagi kelangsungan usaha perusahaan. Untuk mendapatkan loyalitas pelanggan, Gojek melakukan inovasi dalam hal periklanan. Selain itu, Gojek juga menawarkan berbagai layanan yang dengan mudah dapat dipilih oleh pelanggan. Gojek menawarkan beberapa variasi jasa layanan yang dapat memudahkan pelanggan. Kemudahan-kemudahan yang disediakan oleh Gojek membuat pelanggan merasa nyaman dan akhirnya beralih menggunakan jasa Gojek.

Setelah menguraikan latar belakang masalah diatas, maka penulis ingin meneliti lebih jauh masalah tersebut sehingga peneliti ingin mengungkapkan sejauh mana "PENGARUH FUNGSI IKLAN DAN CITRA MEREK TERHADAP LOYALITAS PELANGGAN GOJEK"

\section{Rumusan Masalah}

Berdasarkan latar belakang diatas, ditemukan rumusan masalah :

1) Apakah fungsi iklan dapat mempengaruhi loyalitas pelanggan Gojek ?

2) Apakah citra merek mempengaruhi loyalitas pelanggan Gojek ?

3) Apakah fungsi iklan dan citra merek secara bersama-sama mempengaruhi loyalitas pelanggan Gojek ?

\section{Tujuan Penelitian}

Berdasarkan rumusan masalah tersebut, maka tujuan dari penelitian ini adalah :

1) Untuk mengetahui apakah fungsi iklan mempengaruhi loyalitas pelanggan Gojek

2) Untuk mengetahui apakah citra merek mempengaruhi loyalitas pelanggan Gojek

3) Untuk mengetahui apakah fungsi iklan dan citra merek mempengaruhi loyalitas pelanggan Gojek 
Kevin, Widayatmoko, Muhammad Adi Pribadi : Pengaruh Fungsi Iklan Dan Citra Merek Terhadap Loyalitas Pelanggan Gojek

\section{Kajian Pustaka}

Menurut Rot Zoil dalam Solihin (2015:147) memberikan penjelasan tentang fungsi iklan ke dalam empat fungsi:isepe

\section{a) Precipitation}

Iklan dapat membuat khalayak untuk membuat keputusan . iklan juga berfungsi untuk meningkatkan kesadaran dan pengetahuan tentang produk tersebut, selain itu iklan juga dapat meningkatkan permintaan.

b) Persuasion

Iklan dapat mempengaruhi khalayak untuk mengikuti informasi yang diberikan. Hal ini meliputi daya tarik emosi, menyampaikan informasi tentang ciri suatu produk, dan membujuk konsumen untuk membeli.

c) Reinforcement

Iklan berfungsi untuk meneguhkan keputusan yang telah diambil khalayak.

d) Reminder

Iklan berfungsi sebagai pengingat produk tersebut dan juga semakin meneguhkan khalayak akan produk tersebut.

Menurut Kotler dalam Dewi (2015 : 12) citra merek adalah kepercayaan konsumen terhadap suatu merek tertentu. Citra merek (brand image) merupakan persepsi yang terbentuk di benak konsumen yang berasal dari pengalaman masa lalu ketika menggunakan merek tersebut. Citra terhadap merek berhubungan dengan preferensi dan sikap terhadap merek tersebut. Konsumen yang memiliki citra yang positif dengan merek tersebut, membuat sikap positif di benak konsumen dan pada akhirnya melakukan pembelian ulang.

Citra merek memiliki beberapa dimensi seperti yang disebutkan oleh Kotler dan Amstrong dalam sondakh (2014:24), di antaranya:

1) Strength

Strength mengarah kepada kekuatan merek tersebut dalam hal tampilan fisik yang tidak dimiliki oleh merek lainnya. Hal terserbut termasuk: penampilan fisik produk, harga dan penampilan dari produk tersebut.

2) Uniqueness

Sementara uniqueness adalah perbedaan dari merek tersebut yang membentuk sebuah ciri khas dari merek tersebut. Hal ini muncul karena produk tersebut memiliki ciri khas dibanding merek lain.

3) Favorability

Favourable mengarah pada kemudahan merek tersebut untuk di ingat oleh pelanggan. Termasuk kelompok ini antara lain: kemudahan dalam diucapkan, kemudahan dalam diingat, maupun kesesuaian citra dan kesan yang terbentuk di benak konsumen.

Menurut Giddens dalam Manurung (2009:18) Loyalitas adalah sebuah pilihan dari konsumen untuk memilih produk tertentu dibandingkan dengan produk lainnya. Menurut Beatty, Kahle, Homer dalam Saputri (2010:19) loyalitas dapat diukur menggunakan beberapa cara yaitu:

1. Urutan pilihan (choice sequence)

Urutan pembelian lebih melihat pola pembelian ulang dari konsumen.

2. Proporsi pembelian (proportion of purchase)

Bagian ini lebih meneliti tentang proporsi dari pembelian konsumen.

3. Preferensi (preference) 
Preferensi lebih menekankan dari niat untuk melakukan pembelian oleh konsumen. "is

4. Komitmen (commitment)

Komitmen lebih menekankan kepada kesetiaan konsumen terhadap produk tersebut.

\section{Metode Penelitian}

Penelitian ini menggunakan metode penelitian kuantitatif, digunakan untuk meneliti pada populasi atau sampel tertentu, pengumpulan data menggunakan instrumen penelitian, analisis data bersifat kuantitatif / statistik, dengan tujuan menguji hipotesis yang telah ditetapkan Sugiyono (2011:8).

Menurut liputan6.com, pengguna Gojek di Jakarta sebesar 8 juta orang, sehingga populasi pada penelitian ini adalah 8 Juta pengguna layanan Ojek Online Gojek di daerah Jakarta. Dalam penelitian ini penulis menggunakan teknik nonprobability sampling (nonprobabilitas) sehingga tidak memberikan kesempatan yang sama bagi anggota populasi untuk diteliti. Teknik menentukan sampel yang digunakan adalah teknik purposive sampling yaitu teknik menentukan sampel dengan kriteria tertentu. Sehingga penulis menentukan sampel dari penelitian ini adalah pengguna Gojek di 5 wilayah Jakarta yaitu Jakarta utara, Jakarta pusat, Jakarta selatan, Jakarta barat dan Jakarta timur.

Operasional Konsep dan Yariabel

\begin{tabular}{|c|c|c|c|}
\hline Variabel & Dimensi & Indikator & Skala Data \\
\hline \multirow[t]{4}{*}{ Fungsi Iklan } & Precipitation & $\begin{array}{l}\text { 1. Mempengaruhi } \\
\text { 2. Menciptakan kesadaran } \\
\text { akan sebuah produk } \\
\text { 3. Menciptakan keputusan } \\
\text { pembelian }\end{array}$ & Ordinal \\
\hline & Persuasion & $\begin{array}{l}\text { 1. Untuk memperkenalkan } \\
\text { informasi produk }\end{array}$ & Ordinal \\
\hline & Reinforcement & $\begin{array}{l}\text { 1. Mempertahankan keputusan } \\
\text { pembelian }\end{array}$ & Ordinal \\
\hline & Reminder & $\begin{array}{l}\text { 1. Mempertahankan ingatan } \\
\text { terhadap produk tersebut }\end{array}$ & Ordinal \\
\hline \multirow[t]{2}{*}{ Citra Merek } & $\begin{array}{l}\text { Kekuatan } \\
\text { (Strength) }\end{array}$ & $\begin{array}{l}\text { 1. Penampilan fisik produk } \\
\text { 2. Keberfungsian semua } \\
\text { fasilitas produk } \\
\text { 3. Harga produk }\end{array}$ & Ordinal \\
\hline & $\begin{array}{c}\text { Keunikan } \\
\text { (Uniqueness) }\end{array}$ & $\begin{array}{l}\text { 1. Easilitas pendukung produk } \\
\text { 2. Yariasi layanan produk } \\
\text { 3. Keunikan produk }\end{array}$ & Ordinal \\
\hline
\end{tabular}


Kevin, Widayatmoko, Muhammad Adi Pribadi : Pengaruh Fungsi Iklan Dan Citra Merek Terhadap Loyalitas Pelanggan Gojek

\begin{tabular}{|c|c|c|c|}
\hline & Eavourable & $\begin{array}{l}\text { 1. Kemudahan produk untuk } \\
\text { diucapkan } \\
\text { 2. Kemampuan produk untuk } \\
\text { diingat pelanggan } \\
\text { 3. Kesesuaian kesan dan citra } \\
\text { produk }\end{array}$ & Ordinal \\
\hline \multirow[t]{4}{*}{$\begin{array}{l}\text { Loyalitas } \\
\text { Pelanggan }\end{array}$} & $\begin{array}{c}\text { Urutan } \\
\text { Pembelian }\end{array}$ & $\begin{array}{l}\text { 1. melakukan pembelian } \\
\text { kembali }\end{array}$ & Ordinal \\
\hline & $\begin{array}{l}\text { Proporsi } \\
\text { Pembelian }\end{array}$ & $\begin{array}{l}\text { 1. lebih sering menggunakan } \\
\text { produk ini daripada produk } \\
\text { pesaing }\end{array}$ & Ordinal \\
\hline & Preferensi & $\begin{array}{l}\text { 1. mengutamakan produk ini } \\
\text { daripada produk lain } \\
\text { 2. merekomendasikan produk } \\
\text { ini kepada orang lain }\end{array}$ & Ordinal \\
\hline & Komitmen & $\begin{array}{l}\text { 1. memiliki komitmen } \\
\text { terhadap merek tersebut } \\
\text { 2. selalu menggunakan } \\
\text { merek tersebut }\end{array}$ & Ordinal \\
\hline
\end{tabular}

\section{Hasil Temuan dan Diskusi}

PT. Gojek Indonesia adalah perusahaan transportasi online asal Indonesia yang didirikan tahun 2010 oleh Nadiem Makarim.

Hasil Uji Validitas Fungsi Iklan

\begin{tabular}{|c|c|c|c|}
\hline Pertanyaan & $\mathbf{r}$ hitung & $r$ tabel & Keterangan \\
\hline IK1 & 0,721 & 0,195 & Valid \\
\hline IK 2 & 0,809 & 0,195 & Valid \\
\hline IK 3 & 0,546 & 0,195 & Valid \\
\hline IK 4 & 0,796 & 0,195 & Valid \\
\hline IK 5 & 0,355 & 0,195 & Valid \\
\hline IK 6 & 0,739 & 0,195 & Valid \\
\hline IK 7 & 0,751 & 0,195 & Valid \\
\hline IK 8 & 0,469 & 0,195 & Valid \\
\hline
\end{tabular}

Hasil Uji Validitas Citra Merek

\begin{tabular}{|c|c|c|c|}
\hline Pertanyaan & r hitung & $r$ tabel & Keterangan \\
\hline CI 1 & 0,431 & 0,195 & Valid \\
\hline CI 2 & 0,330 & 0,195 & Valid \\
\hline CI 3 & 0,437 & 0,195 & Valid \\
\hline $\mathrm{CI} 4$ & 0,542 & 0,195 & Valid \\
\hline CI 5 & 0,363 & 0,195 & Valid \\
\hline CI 6 & 0,495 & 0,195 & Valid \\
\hline $\mathrm{CI} 7$ & 0,282 & 0,195 & Valid \\
\hline CI 8 & 0,268 & 0,195 & Valid \\
\hline CI 9 & 0,474 & 0,195 & Valid \\
\hline
\end{tabular}


Hasil Uji Validitas Loyalitas Pelanggan

\begin{tabular}{|c|c|c|c|}
\hline Pertanyaan & r hitung & $\mathrm{r}$ tabel & Keterangan \\
\hline LY 1 & 0,380 & 0,195 & Valid \\
\hline LY 2 & 0,573 & 0,195 & Valid \\
\hline LY 3 & 0,623 & 0,195 & Valid \\
\hline LY 4 & 0,653 & 0,195 & Valid \\
\hline LY 5 & 0,397 & 0,195 & Valid \\
\hline LY 6 & 0,245 & 0,195 & Valid \\
\hline LY 7 & 0,309 & 0,195 & Valid \\
\hline LY 8 & 0,367 & 0,195 & Valid \\
\hline
\end{tabular}

Jika dilihat dari tabel diatas, semua item pertanyaan untuk variabel fungsi iklan, Variabel citra merek dan variabel loyalitas adalah valid. Semua butir pertanyaan untuk variabel fungsi iklan, Variabel citra merek dan variabel loyalitas adalah valid. Selain itu untuk uji reliabilitas, setelah di hitung, didapatkan hasil 0,877 untuk variabel X1 (Fungsi Iklan), lalu untuk variabel citra merek (X2) di didapat hasil 0,722 dan untuk variabel loyalitas pelanggan (Y) mendapatkan 0,746. Sehingga seluruh variabel tersebut dinyatakan reliabel karena $r$ hitung $>r$ tabel yaitu $>0,60$.

Gambar 1 Uji Normalitas

One-Sample Kolmogorov-Smirnov Test

\begin{tabular}{|ll|r|}
\hline & & \multicolumn{1}{|c|}{$\begin{array}{c}\text { Unstandardized } \\
\text { Residual }\end{array}$} \\
\hline $\mathrm{N}$ & & 100 \\
Normal Parametersa,b & Mean & 0000000 \\
& Std. Deviation & 1,44175801 \\
\cline { 2 - 3 } Most Extreme Differences & Absolute & .076 \\
\cline { 2 - 3 } & Positive & .076 \\
& Negative & -.053 \\
& & .076 \\
\hline Test Statistic & $.167^{\circ}$ \\
\hline
\end{tabular}

Setelah hitung, penulis mendapatkan hasil Asymp. Sig. pada penelitian ini adalah 0, $167>0,05$ sehingga data pada penelitian ini dapat dikatakan normal. Yang berarti distribusi dalam penelitian ini normal. Selain itu, setelah di hitung , penulis mendapatkan hasil untuk Tolerance $0.308>0,1$ dan VIF $3.247<10$. Sehingga penelitian ini dapat dikatakan bebas multikolinearitas. Yang berarti tidak ada hubungan antara variabel bebas pada penelitian ini. Untuk uji keabsahan yang terakhir adalah uji heteroskedasitas. Setelah di hitung , penulis mendapatkan hasil nilai signifikansi untuk variabel fungsi iklan Gojek adalah $0.615>0.05$ dan juga nilai signifikansi untuk variabel citra merek adalah 0,913>0.05 sehingga penelitian ini dikatakan bebas heteroskedastitas. Artinya data dari penelian ini memiliki varian sama antara satu dan yang lainnya.

Gambar 2 Koefisien Korelasi Berganda Correlations

\begin{tabular}{|c|c|c|c|c|}
\hline & & IkJanGoiek & CitraGoiek & Loyalitas \\
\hline \multirow[t]{3}{*}{ IkJanGojek } & Pearson Correlation & 1 & $.832^{*}$ & $.802^{* *}$ \\
\hline & Sig. (2-tailed) & & .000 & .000 \\
\hline & $\mathrm{N}$ & 100 & 100 & 100 \\
\hline \multirow[t]{3}{*}{ CitraMerek } & Pearson Correlation & $.832^{* *}$ & 1 & $.904^{*}$ \\
\hline & Sig. (2-tailed) & .000 & & .000 \\
\hline & $\mathrm{N}$ & 100 & 100 & 100 \\
\hline \multirow[t]{3}{*}{ Lexalitas } & Pearson Correlation & $.802^{*}$ & $.904^{*}$ & 1 \\
\hline & Sig. (2-tailed) & .000 & .000 & \\
\hline & $\mathrm{N}$ & 100 & 100 & 100 \\
\hline
\end{tabular}


Kevin, Widayatmoko, Muhammad Adi Pribadi : Pengaruh Fungsi Iklan Dan Citra Merek Terhadap Loyalitas Pelanggan Gojek

Setelah di hitung, penulis mendapatkan hasil bahwa nilai korelasi (r) dari variabel $\mathrm{X} 1 \mathrm{ke} \mathrm{Y}$ dalam penelitian ini sebesar 0.802 dengan pengaruh positif dan kuat. Artinya semakin tinggi fungsi iklan maka loyalitas juga semakin tinggi. Selain itu, didapatkan bahwa nilai korelasi ( $r$ ) dari variabel X2 ke $\mathrm{Y}$ dalam penelitian ini sebesar 0.904 dengan pengaruh positif dan kuat. Artinya semakin tinggi citra merek maka loyalitas juga semakin tinggi.

Gambar 3 Regresi Linear Berganda Coefficients ${ }^{a}$

\begin{tabular}{|c|c|c|c|c|c|c|}
\hline \multirow{2}{*}{\multicolumn{2}{|c|}{ Model }} & \multicolumn{2}{|c|}{ Unstandardized Coefficients } & \multirow{2}{*}{$\begin{array}{c}\text { Standardized } \\
\text { Coefficients } \\
\text { Beta } \\
\end{array}$} & \multirow[b]{2}{*}{ ts } & \multirow[b]{2}{*}{ Sig. } \\
\hline & & $\mathrm{B}$ & Std. Error & & & \\
\hline \multirow[t]{3}{*}{1} & (Constant) & $-1,135$ & 1,538 & &,- 738 & ,000 \\
\hline & IklanGojek & , 154 & ,072 & , 164 & 2,138 & ,035 \\
\hline & CitraMerek & ,760 &, 076 & ,767 & 10,021 &, 000 \\
\hline
\end{tabular}

a. Dependent Variable: Loyalitas

$$
\begin{gathered}
Y=\alpha+b 1 X 1+b 2 X 2 \\
Y=-1.135+0.154 X 1+0.760 X 2
\end{gathered}
$$

Setelah di hitung, penulis mendapatkan hasil konstanta sebesar -1.135 yang berarti bahwa nilai konsisten loyalitas pelanggan adalah sebesar -1.135. Nilai koefisien regresi untuk variabel fungsi Iklan adalah sebesar 0.154, ini menunjukan bahwa fungsi iklan gojek memiliki pengaruh terhadap loyalitas pelanggan. Sedangkan nilai koefisien regresi citra gojek adalah sebesar 0.760 . Koefisien regresi tersebut bernilai positif, sehingga dapat diartikan bahwa arah pengaruh variabel $\mathrm{X}$ terhadap $\mathrm{Y}$ adalah positif. Hal ini dapat disimpulkan bahwa semakin tinggi peningkatan fungsi iklan dan citra merek Gojek maka akan semakin menambah loyalitas pelanggan. Selain itu untuk analisis koefisien determinasi, setelah di hitung , penulis mendapatkan hasil $\mathrm{R}$ Square sebesar 0,825 yang artinya variabel independen (fungsi iklan dan Citra merek) dapat menjelaskan variabel dependen (Loyalitas pelanggan) sebesar 82,5\% dan sisanya sebesar 17,5\% dipengaruhi oleh variabel lainnya.

Berdasarkan hasil diatas, dapat dilihat nilai Sig. Variabel fungsi iklan sebesar 0,035 dan juga nilai sig untuk variabel citra merek sebesar 0.000. Dapat dilihat dari kedua nilai sig variabel fungsi iklan dan citra merek $<0,05$ maka Ha diterima. Sehingga dapat dikatakan bahwa variabel fungsi iklan mempengaruhi secara signifikan variabel loyalitas pelanggan dan juga variabel citra merek mempengaruhi secara signifikan variabel loyalitas pelanggan.

Setelah di hitung, penulis mendapatkan hasil dengan menggunakan tingkat keyakinan sebesar 95\%, a=5\% (0.05), maka Ftabel sebesar 3.0902 yang didapat dari melihat df $1=2$ dan df $2=97$. Sehingga dengan ketentuan diatas maka dapat disimpulkan bahwa Fhitung > Ftabel $(228.333$ > 3.0902), maka Ho ditolak yang artinya ada pengaruh signifikan fungsi iklan Gojek dan Citra Gojek seara bersamasama terhadap Loyalitas pelanggan Gojek.

\section{Kesimpulan}

Sehingga dapat disimpulkan bahwa, diketahui bahwa variabel fungsi iklan mempengruhi secara signifikan terhadap loyalitas pelanggan dan juga variabel citra merek mempengaruhi secara signifikan variabel loyalitas pelanggan dengan temuan bahwa pada variabel fungsi iklan, dimensi persuasion (membujuk) dan reinforcement 
(meneguhkan) adalah dimensi yang paling berpengaruh terhadap loyalitas pelanggan dan pada variabel citra merek, dimensi keunikan adalah dimensi yang paling berpengaruh terhadap loyalitas pelanggan. Sehingga secara keseluruhan dapat disimpulkan bahwa fungsi iklan dan citra merek Gojek mempengaruhi Loyalitas pelanggan Gojek.

\section{Ucapan Terima Kasih}

Penulis sangat berterima kasih kepada Bapak Drs. Widayatmoko, M.M.,M.I.Kom sebagai Dosen Pembimbing dan juga Bapak Muhammad Adi Pribadi, S.E., M.I.B.,M.Comm., Dr selaku Co-Pembimbing yang telah meluangkan waktunya untuk memberikan bimbingan sehingga penulis akhirnya mengerti cara meneliti dan membuat skripsi yang baik. Selain itu untuk orang tua dan teman dan juga sahabat penulis yang sudah memberikan dukungan.

\section{Daftar Pustaka}

Dewi, N. K., \& SE, G. A. (2012). Pengaruh Iklan, Citra Merek, dan Kepuasan Konsumen Terhadap Loyalitas Konsumen dalam Menggunakan Vaseline Hand and Body Lotion di Kota Padang (Studi Kasus di PT. Unilever Cabang Padang). Sumber, 6(1), 26.

Manurung, D. S. (2009). Pengaruh kepuasan konsumen terhadap loyalitas merek pada pengguna kartu pra-bayar simpati.

Solihin, O. (2015). Terpaan Iklan Mendorong Gaya Hidup Konsumtif Masyarakat Urban. Jurnal Ilmu Politik dan Komunikasi Volume V No.

Sondakh, C. (2015). Kualitas Layanan, Citra Merek Dan Pengaruhnya Terhadap Kepuasan Nasabah Dan Loyalitas Nasabah Tabungan (Studi Pada Nasabah Taplus BNI Cabang Manado). Jurnal Riset Bisnis dan Manajemen, 3(1).

Sugiyono. (2011). Metode penelitian pendidikan (pendekatan kuantitatif, kualitatif, dan $R \& D)$. bandung: alfabeta. 